\title{
Importance of arterial stiffness in predicting cardiovascular events
}

\author{
MONICA ECOBICI, M. VOICULESCU \\ Clinic of Internal Medicine, Fundeni Clinical Institute, Bucharest
}

\begin{abstract}
Introduction. Cardiovascular events represent an important cause of morbidity and mortality in the entire population. Arterial stiffness is currently considered one of the most important risk factors for the development of cardiovascular events. The gold-standard for evaluating arterial stiffness is pulse wave velocity (PWV). Recent studies have demonstrated that PWV is an independent risk factor regarding the development of cardiovascular events, especially in certain categories of patients.

Material and Methods. The development of cardiovascular events was assessed in 174 patients admitted in the Center of Internal Medicine, Fundeni Clinical Institute, between January 2011 - May 2012. Arterial stiffness was evaluated by measuring PWV using the Sphygmocor system (AtCor, Australia), which is based on the principle of applanation tonometry. The patients were monitored for the development of cardiovascular events (ischemic heart disease, heart failure, stroke, acute myocardial infarction) and for death of cardiovascular cause, over a median period of 51.5 months (43-60 months).

Results. Of the 174 patients, 81 (46.6\%) were women and $93(53.4 \%)$ were men. Mean age was 55.96 years. 93 of the 174 patients had chronic kidney failure in different stages $(47.3 \%$ in stage V). Regarding PWV in the patient group, we obtained a mean score of 9.382. We observed a significant difference regarding the PWV level only for acute myocardial infarction and death between patients who developed these events and those who did not.

Conclusions. Our study demonstrates that PWV increase can be positively associated with the occurrence of cardiovascular events, particularly in certain groups of patients
\end{abstract}

Keywords: pulse wave analysis, cardiovascular, risk factors, vascular stiffness.

\section{INTRODUCTION}

Coronary heart disease and stroke are important causes of morbidity and mortality all over the world [1-3]. Many epidemiological data have shown that in the general population, coronary accidents are frequent and have a high rate of mortality. The most affected categories of populations are males older than 60 years, smokers, or with associated comorbidities, such as Diabetes Mellitus, hypertension, dyslipidemia, chronic kidney diseases etc. [4]). All of these risk factors are associated with important changes of structural and functional characteristics of the arterial wall. Anatomical studies have demonstrated the presence not only of the atheroma lipid plaque, but also of important lesions of inflammation and fibrosis. These histological changes significantly change the physical properties of the arterial walls which became more rigid and lost their elasticity [5-7]. In uremic patients the magnitude and the dynamic process of atherosclerosis is higher and faster than in the general population and, as a consequence, cardiovascular accidents and stroke are frequent and become the main cause of mortality $(>70 \%)$ [8-11].
The arterial wall is not a rigid structure but an elastic system. Along the arterial system the magnitude of elasticity changes according to the structure of the arterial wall. The proximal aorta has different characteristics as opposed to the distal arterial system. The most important function of the proximal aorta is to accept the stroke volume of the left ventricle and to pomp the blood not only in the systemic arterial circulation, but also in the coronary arteries during diastole. Therefore, the rigidity of the proximal aorta would impede the vascularization and the supply with oxygen of the left ventricular myocardium. In time, a rigid proximal aorta would impede limit the ejection of the blood and significantly rise the demand of oxygen by the left ventricular myocardium. By this way the ratio between demand and the supply of oxygen is compromised [1, 12-16].

Arterial stiffness (AS) is now considered one of the best markers of arterial rigidity and an important risk factor for possible cardiovascular accidents $[2,3,14,17,18]$. The direct atherogenic effects of many factors, such as hypertension, dislipidemia, diabetes mellitus, smoking or uremic milieu, can increase AS by many ways, including 
induction of arteriosclerosis (presence of fibrosis in arterial wall) and atherosclerosis (presence of lipid plaque).

AS can easily be measured by counting the wave velocity between different sites of the arterial tree. There is a mathematical relationship between the velocity of the wave and the magnitude of fibrosis; velocity is higher as arterial stiffness increases. As the arterial wall loses its elasticity and becomes rigid the PWV increase according to a mathematical formula which allows us to measure and quantify the changes in the arterial wall $[19,20]$.

The aortic PWV index provides additional predictive value above the classical cardiovascular risk factors. Therefore, measurement of arterial stiffness as an independent risk factor can be used to better approximate the true risk of coronary heart disease. As a consequence of arterial stiffness systolic blood pressure increases, generating an important rise in the left ventricle workload, which leads to oxygen consumption, ischemia, and left ventricle hypertrophy [21]. Recent studies have shown that carotid distensibility and the aortic PWV can be considered valid predictors for cardiovascular events at least in patients with hypertension and end stage renal disease [22-24]. Several studies have shown that aortic PWV offers the best prediction for cardiovascular events in patients with end-stage renal disease and in patients with hypertension [10, 11]. A recent study among elderly patients has shown that PWV independently predicts cardiovascular mortality [25]. The main weaknesses of these studies are that the patients are only males and the number of patients is statistically low.

\section{MATERIALS AND METHODS}

In this study we have observed the occurrence of cardiovascular events in 174 patients admitted in the Internal Medicine and Nephrology Clinic, Fundeni Clinical Institute during 01.2011-05.2012. The patients were assessed both clinically and biologically and we determined the seric values of BUN, creatinine, total cholesterol, glucose (using Konelab 60i system), calcium and phosphorus (using Dimension RXL Chemistry System), PTH (using Advia Centaur XP System). The patients also underwent a procedure to measure the arterial stiffness by measuring pulse wave velocity (PVW), as well as other parameters (central aortic blood pressure - CAP, pulse pressure in the Aorta - PPA, augmentation index - Aix, endocardium viability ratio - EVR, ejection duration of the left ventricle EjD). The vascular rigidity was measured using the Sphygmocor system (AtCor, Australia), which utilizes the principle of applanation tonometry to determine in a non-invasive manner the central pressure and pulse wave by analyzing it in the radial artery.

Measuring the peripheral arterial tension (at the brachial artery) was done using an Omron blood pressure monitor. The patients were examined à jeun, after a 10 min resting period in supine position. The patients that underwent renal replacement therapy were examined as such: the patients that underwent peritoneal dialysis were measured after the peritoneal liquid had been drained from the peritoneal cavity; in case of hemodialysis, they were examined in the day that they did not have to undergo the hemodialysis session. Patients with atrial fibrillation and moderate to severe aortic valvulopathy were excluded from the study.

After the patients underwent the measurement procedure, they were followed-up for an average period of 51.5 months (43-60 months) in order to record the appearance of cardio-vascular events (acute myocardial infarction, stroke, ischemic heart disease, cardiac insufficiency).

The statistical analysis and graphical representations were done using SPSS 20. Several statistical functions were used to analyze the data, including: ANOVA one way test, Spearman correlation coefficient, $\mathrm{t}$ test for independent samples.

\section{RESULTS}

Of the 174 patients analyzed, $81(46.6 \%)$ were women and $93(53.4 \%)$ were men. The patients had a mean age of 55.96 years (20-87).

93 of them were diagnosed with chronic kidney disease (CKD), most being CKD stage $\mathrm{V}$ (47.3\%); $18.3 \%$ stage were stage IV, $29 \%$ stage III and $5.4 \%$ stage II. 40 patients were included into a renal replacement therapy program, 22 being on peritoneal dialysis and 18 on hemodialysis. Regarding their comorbidities, $63.76 \%$ of the patients were hypertensive, $15.51 \%$ were diabetic and $40.22 \%$ had dyslipidemia.

The mean value of the measured pulse wave velocity (PWV) was $9.382( \pm 3.29)$. PWV was then compared with the comorbidities and the renal stage to see if there was any correlation between them. 
There was no statistical difference regarding the renal stage groups (stages II-V) in respect to the PWV $(\mathrm{p}=0.826)$. PWV value was significantly higher in diabetic patients (Figure 1). The nondiabetic patients had a mean PWV value of 9.138 $(\mathrm{SD}=3.27)$, whilst the diabetic patients had a mean value of 10.663 (SD = 3.14). Interestingly, there was a significant difference between the two types of arterial hypertension - primary and secondary renal hypertension. The number of patients with essential hypertension was 62 , and those with secondary renal hypertension was 52 .

Patients with primary hypertension have a higher $\mathrm{PWV}$ value $(\mathrm{PWV}=10.362 ; \mathrm{SD}=3.66)$ than those with secondary renal hypertension $(\mathrm{PWV}=8.833 ; \mathrm{SD}=3.14)$ (Figure 2). There was no significant difference between the PWV values in respect to the dyslipidemia status (Figure 3).

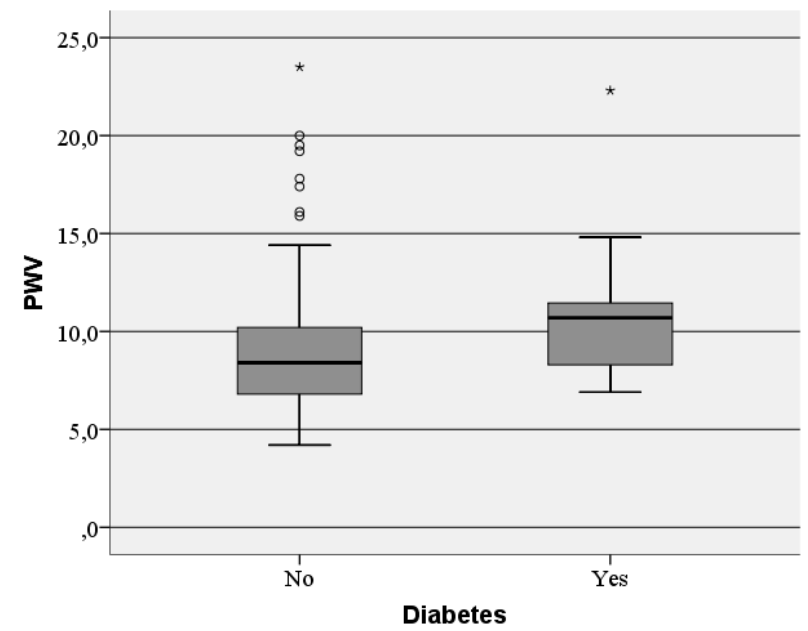

Figure 1. Pulse wave velocity in patients with diabetes.

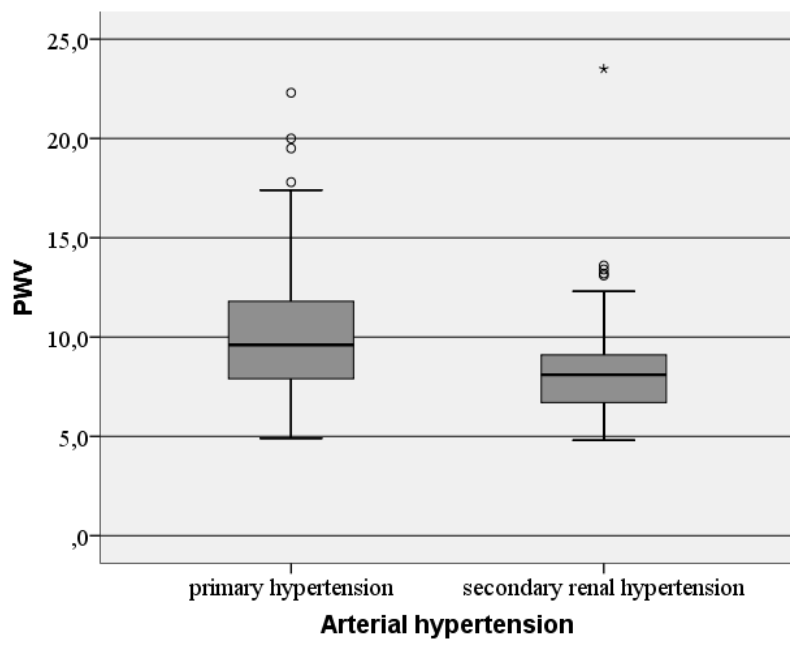

Figure 2. Pulse wave velocity in patients with hypertension.

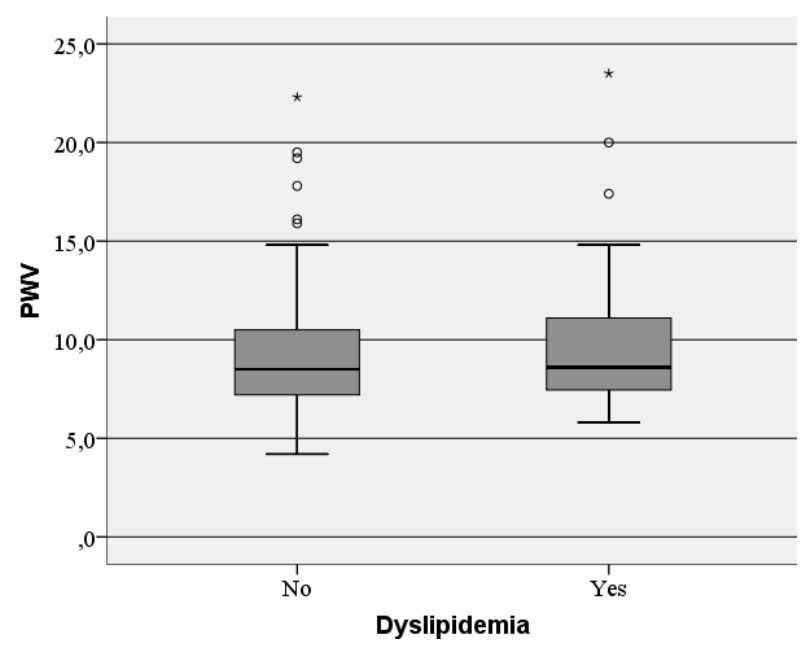

Figure 3. Pulse wave velocity in patients with dyslipidemia.

We also compared the PWV to the patients' biological parameters. There was a significant positive correlation between the PWV value and the BUN seric levels (rho $=0.272 ; \mathrm{p}=0.04$ ), although such correlation was not observed with the creatinine levels. The PWV value also positively correlated with the phosphorus ( $r$ o $=0.340 ; \mathrm{p}=$ $0.041)$ and glucose (rho $=0.185 ; \mathrm{p}=0.010$ ) levels. There was also a negative correlation between the PWV value and the hemoglobin level (rho = -0.248 ; $\mathrm{p}=0.004$ ). Other parameters analysed (cholesterol, calcemia, PTH) did not influence the PWV value.

PWV value is positively correlated with the aortic systolic blood pressure ( $($ ho $=0.311 ; \mathrm{p}<0.01)$ and the aortic diastolic blood pressure (rho $=0.294$; $\mathrm{p}<0.01$ ) as well as the pulse pressure (rho $=0.172$; $\mathrm{p}=0.026)$. There was also a negative correlation between PWV value and subendocardial viability ration SEVR (rho $=-0.157 ; p=0.04$ ), meaning that a higher PWV is consistent with a lower SEVR value.

The patients' cardiovascular events (death from cardiovascular cause, acute coronary syndrome, ischemic heart disease, stroke, heart failure) were analyzed and compared to the PWV value. There was a significant difference between PWV value to patients with acute coronary syndrome and patients without acute coronary syndrome. Patients who, for the follow-up period, experienced an acute coronary syndrome had a mean PWV value of 13.656 (SD = 15.12), compared to the others who had an average PWV value of 9.141 ( $S D=3.00 ; \mathrm{p}<0.01)$. There was also a significant correlation between PWV and death from cardiovascular cause $(\mathrm{p}=0.038)$.

Using Cox regression analysis, we calculated the curve of "survival" in the presence of ischemic heart disease, heart failure, acute coronary syndrome 
or stroke in patients with different stages of chronic kidney disease and according to PWV value. Since we do not have a variable that shows how long the patient has the chronic kidney disease, we used the variable "age". In this case "survival" means the age at which the event occurred (in our case ischemic heart disease, heart failure, acute coronary syndrome or stroke).

The results that we have obtained showed that, although the risk of cardiovascular events increases in patients with advanced chronic kidney disease, this risk is not augmented by an increase in PWV.

\section{DISCUSSION}

Current studies have shown that central arterial stiffness (measured by pulse wave velocity in the carotid or femoral artery) is influenced especially by age and central blood pressure; it is also an independent predictor of cardiovascular events and cardiovascular mortality in all types of patients, those who have comorbidities (diabetes, chronic kidney disease), as well as in apparently healthy individuals.

It is considered that evaluating the cardiovascular risk using PWV is more accurate regarding the patients' individual risk for developing cardiovascular events, because unlike the Framingham score which is based on instant cardiovascular risk factors, PWV is influenced by the rigidity of the arterial wall that appears in time and shows the chronic alteration of the vessels.

Our study analyzed 174 patients, some who had comorbidities (diabetes, chronic kidney disease) and observed the appearance of cardiovascular events (including death from a cardiovascular cause) for a period of 51.5 months. Our objective was to see if there was any correlation between the cardiovascular events and the value of PWV measured in the beginning of the study. The results showed that in the presence of chronic kidney disease, diabetes or hypertension, PWV value was significantly higher (without there being any difference between the stages of CKD).

We also tried to compare the PWV value to the patients' biological parameters. We observed a positive correlation between PWV and phosphorus (rho $=0.185, \mathrm{n}=123, \mathrm{p}=0.041)$ and glucose $(\mathrm{rho}=$ $0.340, \mathrm{n}=57, \mathrm{p}=0.010)$ levels. There was also a negative correlation between the PWV value and the hemoglobin level (rho $=-0.248, \mathrm{n}=134, \mathrm{p}=$ 0.004).

During the follow-up period, $19 \%$ of the patients included in the study were diagnosed with ischemic heart disease and $14.4 \%$ were diagnosed with heart failure (using ultrasound criteria). 9 patients $(5.2 \%)$ suffered an acute coronary syndrome and 14 patients (8\%) had at least one stroke. Death from a cardiovascular cause was recorded in 18 cases $(10.3 \%)$.

Although in patients with acute coronary events and deaths due to cardiovascular cause, PWV value was significantly higher, and PWV value was significantly higher in the presence of chronic kidney disease, diabetes or hypertension, statistical analysis does not claim that an elevated PWV increases the risk of additional cardiovascular events in these patients.

The Rotterdam study evaluated 7983 patients (apparently healthy population), with average age $71.7 \pm 6.7$ years, who were followed for the occurrence of coronary heart disease and stroke. Study results showed that PWV is a strong and independent predicting factor for the occurrence of stroke and coronary heart disease in the general population (apparently healthy) [3].

In a meta-analysis of 17 published studies, 15877 patients were followed over a mean period of 7.7 years. It was assessed the risk of cardiovascular events, cardiovascular mortality and allcause mortality. It was found that in the group with PWV increased risk of cardiovascular events, cardiovascular mortality and all-cause mortality was the middle two times higher than in the group with low PWV. Also, the results of this metaanalysis have shown that the predictive value of PWV was higher in patients who had a disease with high cardiovascular risk (for example, chronic kidney disease) [4].

These results are partially consistent with the results obtained in our study. Possible explanations for this could be a much larger number of patients, a longer follow-up period, the heterogeneity of PWV calculation methods and for methods of measuring carotid-femoral distance and lack of established cutoff values for PWV.

The limitations of our study are represented by the small number of patients and by the lack of certain biological variables that were not available at the time of the patients' enrollment in the study, as well as the lack of autopsy results to confirm the cause of death in certain cases. 


\section{CONCLUSIONS}

PWV increase can be positively associated with the occurrence of cardiovascular events, particularly in certain groups of patients.

The measurement of arterial stiffness could be considered one of the best methods to monitor the status of the arterial system, it is easy to perform, reproducible and cheap. Probably it needs new studies with a large numbers of patients to determine with certainty the predictive role of PWV in terms of cardiovascular events.

Statement: There is no conflict of interest.

Introducere. Evenimentele cardiovasculare reprezintă o cauză importantă de morbiditate şi mortalitate la nivel populațional. Rigiditatea arterială este considerată ca fiind unul dintre cei mai importanți factori de risc pentru dezvoltarea evenimentelor cardiovasculare. Standardul de aur pentru evaluarea rigidității arteriale este reprezentată de analiza vitezei de propagare a undei de puls $(P V W)$. Studii recente sugerează faptul că $P W V$ este un factor de risc independent pentru dezvoltarea evenimentelor cardiovasculare mai ales la unele categorii de pacienți.

Materiale şi Metode. Au fost evaluate evenimentele cardiovasculare la 174 de pacienți internați în cadrul Clinicii de Medicină Internă a Institutului Clinic Fundeni în perioada ianuarie 2011 - mai 2012. Rigiditatea arterială a fost măsurată folosind PWV cu sistemul Spygmocor (AtCor, Australia) bazat pe principiul tonometriei de aplanare. Pacienții au fost monitorizați o perioada medie de 51.5 luni (43-60 luni) pentru dezvoltarea evenimentelor cardiovasculare (boală cardiacă ischemică, insuficiență cardiacă, atac vascular cerebral, infarct miocardic acut) şi pentru apariția morții datorată evenimentelor cardiovasculare.

Rezultate. Din cei 174 de pacienți, 81 (46.6\%) au fost de gen feminin şi 93 (53.4\%) au fost de gen masculin. Vârsta medie a fost de 55.96 ani. 93 din cei 174 pacienți au avut boală renală în diferite stadii (47.3\% in stadiul V). Scorul mediu al PWV a fost de 9.382. Am observat o diferență semnificativă statistic între pacienții care au suferit infarct miocardic acut şi pacienții care au suferit deces, comparativ cu ceilalți pacienți.

Concluzii. Studiul demonstrează faptul că o creştere a PWV este asociată cu apariția evenimentelor cardiovasculare, mai ales la anumite grupuri de pacienți.

Correspondence to: Monica Ecobici, M.D

Fundeni Clinical Institute, Şos. Fundeni, 258, sector 2, Bucharest, 022328

Telephone/fax: 0040723666051/00213120991

E-mail: ecobicimonica@yahoo.com

\section{REFERENCES}

1. BOUTOUYRIE P, FLISER D, GOLDSMITH D,COVIC A, WIECEK A, ORTIZ A et al. Assessment of arterial stiffness for clinical and epidemiological studies: methodological considerations for validation and entry into the European renal and cardiovascular medicine registry. Nephrol Dial Transplant (2014) 29:232-239.

2. PALOMBO C, KOZAKOVA M. Arterial stiffness, atherosclerosis and cardiovascular risk: Pathophysiologic mechanism and emerging clinical indications. Vascul. Pharmacol (2015), http://dx.doi.org/10.1016/j.vph.2015.11.083.

3. MATTACE-RASO FUS, VAN DER CAMMEN TJM, HOFMAN A, VAN POPELE NM, BOS ML, SCHALEKAMP M, et al. Arterial stiffness and risk of coronary heart disease and stroke: the Rotterdam Study. Circulation.2006, 113:657-663.

4. VLACHOPOULOS C, AZNAOURIDIS K, STEFANADIS C. Prediction of cardiovascular events and all-cause mortality with arterial stiffness: a systematic review and meta-analysis. J Am Coll Cardiol 2010; 55:1318-27.

5. XU C, ZARINS CK, PANNARAJ PS, BASSIOUNY HS, GLAGOV S. Hypercholesterolemia superimposed by experimental hypertension induces differential distribution of collagen and elastin. ArteriosclerThrombVasc biol. 2000; 20:2566-2572.

6. MITCHELL GF, LACOURCIÈRE Y, OUELLET J-P, IZZO JL, NEUTEL J, KERWIN LJ, et al. Determinants of elevated pulse pressure in middle-aged and older subjects with uncomplicated systolic hypertension: the role of proximal aortic diameter and the aortic pressure-flow relationship. Circulation.2003; 108:1592-1598. 
7. JACOB MP. Extracellular matrix remodeling and matrix metalloproteinases in the vascular wall during aging and in pathological conditions. Biomed Pharmacother. 2003; 57:195-202.

8. BRIET M, BOUTOUYRIE P, LAURENT S, LONDON GM. Arterial stiffness and pulse pressure in CKD and ESRD. Kidney Int 2012; 82:383-400.

9. LONDON GM, DRÜEKE TB. Atherosclerosis and arteriosclerosis in chronic renal failure. Kidney Int 1997; 51:1678-1695.

10. BLACHER J, GUERIN AP,PANNIER B, MARCHAIS SJ, SAFAR ME, LONDON GM. Impact of aortic stiffness on survival in end-stage renal failure. Circulation.1999, 99:2434-2439.

11. BLACHER J, PANNIER B, GUERIN AP, MARCHAIS SJ, SAFAR ME, LONDON GM. Carotid arterial stiffness as a predictor of cardiovascular and all-cause mortality in end-stage renal disease. Hypertension 1998, 32:570-574.

12. MACKENZIE IS, WILKINSON IB, COCKROFT JR. Assessment of arterial stiffness in clinical practice. Q J Med2002; 95:67-74.

13. LAURENT S, COCKCROFT J, VAN BORTEL L, BOUTOUYRIE P, GIANNATTASIO C, HAYOZ D, et al. Expert consensus document on arterial stiffness: methodological issues and clinical applications. European Heart Journal (2006) 27, 2588-2605.

14. SAKURAGI S, ABHAYARATNA WP. Arterial stiffness: Methods of measurement, physiologic determinants and predictio of cardiovascular outcomes. International Journal of Cardiology 138 (2010)112-118.

15. LONDON GM. Mechanisms of arterial calcifications and consequences for cardiovascular function. Kidney International Supplements (2013) 3, 442-445.

16. ZIEMAN SJ, MELENOVSKY V, KASS DA. Mechanism, pathophysiology and therapy of arterial stiffness. ArteriosclerthrombVasc Biol. 2005; 25:932-943.

17. IKONOMIDIS I, MAKAVOS G, LEKAKIS J. Arterial stiffness and coronary artery disease. Curr.Opin.Cardiol.30 (2015) $422-431$.

18. MITCHELL GF, HWANG SJ, VASAN RS, LARSON MG, PENCINA MJ, HAMBURG NM, et al. Arterial stiffness and cardiovascular events: the Framingham Heart Study. Circulation 121 (2010) 505-511.

19. LACOLLEY P. Genetics and pathophysiology of arterial stiffness. Cardiovascular Research (2009) 81, 637-648.

20. QUINN U, TOMLINSON LA, COCKCROFT JR. Arterial stiffness. J R Soc Med Cardiovasc Dis 2012;1:18.DOI $10.1258 /$ cvd.2012.012024.

21. O'ROURKE MF. Wave reflection in the systemic circulation and its implications in ventricular function. J Hypertens.1993, 11:327-337.

22. LAURENT S, BOUTOUYRIE P, ASMAR R, GAUTIER I, LALOUX B, GUIZE L, et al. Aortic stiffness is an independent predictor of all-cause and cardiovascular mortality in hypertensive patients. Hypertension.2001; 37:1236-1241.

23. DUDENBOSTEL T, GLASSER SP. Effects of antihypertensive drugs on arterial stiffness. Cardiol rev. 2012; 20(5): doi;10.1097/CRD.0b013e31825d0a44.

24. SAFAR M, LONDON G. Theraputic studies and arterial stiffness in hypertension: recommendations of the European Society of Hypertension. The Clinical Committee of Arterial Structure and Function. Working Group on Vascular Structure and Function of the Eutopean Society of Hypertension. J Hypertens.2000; 18:1527-1535.

25. KOZAKOVA M, MORIZZO C, GUARINO D, FEDERICO G, MICCOLI M, GIANNATTASIO C et al. The impact of age and risk factors on carotid and carotid-femoral pulse wave velocity. J. Hypertens. 33 (2015) 1446-1451.

Received June 3, 2016 